\title{
BIMBINGAN DAN KONSELING BELAJAR: MANAGEMEN WAKTU PENGHAFAL AL-QUR'AN DALAM MERAIH PRESTASI AKADEMIK
}

\author{
Hafisa Idayu \\ Pascasarjana UIN Sunan Kalijaga Yogyakarta, Indonesia \\ hafisaidayu@gmail.com
}

\begin{abstract}
Abstrak
Penelitian ini bertujuan untuk mengetahui Bimbingan dan konseling belajar: managemen waktu penghafal Al-qur'an dalam meraih prestasi akademik. Metode yang digunakan dalam penelitian ini adalah metode kualitatif dengan pendekatan deskriptif dan membahas tentang pembagian dan pengaturan waktu seorang penghafal al-Qur'an dalam meraih prestasi di bidang akademik. Hasil dari penelitian menunjukkan bahwa selain menghafal al-Quran, subjek juga mampu meraih prestasi akademik. Dalam penelitian terdapat 4 cara atau metode yang digunakan kedua subjek dalam mamenggunakan waktu mereka dengan maksimal, yaitu: menetapkan tujuan dan prioritas, perencanaan dan penjadwalan, kemampuan mengendalikan waktu dan evaluasi.
\end{abstract}

Kata Kunci: Belajar, Manajemen waktu, Prestasi Akademik

\begin{abstract}
Guidance And Learning Counseling: Management Of Al-Qur'an Memorization Time In Achieving Academic Achievement. This study aims to determine the guidance and learning counseling: management of Al-Qur'an memorization time in achieving academic achievement. The method used in this research is a qualitative method with a descriptive approach and discusses the division and timing of an alQur'an memorizer in achieving academic achievements. The results of the study showed that in addition to memorizing the Koran, the subject was also able to achieve academic achievement. In research there are 4 ways or methods used by both subjects in using their time to the
\end{abstract}


maximum, namely: setting goals and priorities, planning and scheduling, ability to control time and evaluation.

Keywords: Learning, Time Management, Academic Achievement

\section{A. Pendahuluan}

Dalam lampiran permendikbud nomor 111 dijelaskan bahwa pengertian Bimbingan dan konseling belajar adalah proses pemberian bantuan konselor atau guru bimbingan dan konseling kepada peserta didik/konseli dalam mengenali potensi diri untuk belajar, memiliki sikap dan keterampilan belajar, terampil merencanakan pendidikan, memiliki kesiapan menghadapi ujian, memiliki kebiasaan belajar teratur dan mencapai hasil belajar secara optimal sehingga dapat mencapai kesuksesan, kesejahteraan dan kebahagiaan dalam kehidupannya (Octavia, 2019: 53).

Setiap siswa memiliki kebiasaan belajar yang berbeda-beda begitupula dengan cara memahami pelajaran yang disampaikan oleh guru. Selain itu siswa juga memimiliki gaya belajar yang berbeda seperti visual,auditory dan kinestetik. Oleh sebab itu dalam hal ini guru harus mampu memahami siswanya dan memiliki metode mengajar tersendiri. Memiliki metode belajar yang baik tentu akan menciptakan hasil belajar yang baik pula.

Kebanyakan siswa memiliki kegiatan atau kesibukan diluar sekolah seperti halnya kegiatan menghafal al-Qur'an.Menghafal al-Quran merupakan sebuah bentuk aktivitas yang bertujuan untuk menjaga serta melestarikan keasliaannya dengan cara memasukkan ayat-ayat al-Quran ke dalam hati dan pikiran agar tertanam di dalamnya. Proses menghafal bersifat personal dan individual, sehingga dalam menghafalkan al-Qur'an di butuhkan kegigihan dan kedisiplinan agar hafalan tersebut tetap terjaga dan terserap kedalam memori jangka panjang individu. Oleh sebab itu bagi seorang hafidz (Sebutan untuk penghafal Al-Qur'an) 
tidak hanya cukup menghafal sampai 30 juz tetapi bagaimana mereka bisa mempertahankan hafalan tersebut.

Menghafal al-Qur'an termasuk ibadah apabila dilakukan dengan hati yang ikhlas tanpa mengharapkan pujian dari orang lain. Salah satu ciri orang yang berilmu menurut standar al-Qur'an adalah mereka yang memiliki hafalan al-Qur'an sebagaimana yang terdapat dalam Q.S al-Ankabut ayat 49 yang artinya: Sebenarnya, Al Quran itu adalah ayat-ayat yang nyata di dalam dada orang-orang yang diberi ilmu

Dahulu seorang penghafal al-Qur'an banyak di temukan dalam lingkugan pondok pesantren dan di Masjid khusus untuk menghafal al-Qur'an. Biasanya mereka hanya fokus menghafal al-Qur'an tanpa di sibukkan dengan urusan-urusan yang lain. Namun di zaman sekarang para penghafal al-Qur'an tidak hanya unggul dalam bidang hafalan, tetapi banyak di antara mereka juga berkecimpung dalam dunia pendidikan hingga organisasi. Hal ini murupakan perubahan positif di mana penghafal al-Qur'an tidak hanya berdiam diri didalam masjid tetapi juga memiliki aktivitas lain yang untuk mengembangkan potensi mereka.

Dalam dunia pendidikan pun banyak di antara para penghafal al-Quran yang mampu bersaing dalam meraih prestasi akademik begitu pula dalam organisasi, mereka mampu menjalani tugas dengan baik, dan tak jarang kita lihat penghafal al-Quran menjadi pemimpin dalam suatu organisasi. Dalam hal ini para penghafal al-Quran memiliki metode yang berbeda-beda dalam menghafal dan mempertahankan hafalan al-Quran mereka. Salah satunya adalah dengan cara mura'jaah artinya mengulang-ulang hafalan yang telah di peroleh, bisa dilakukan sendiri, disetorkan kembali pada guru, ataupun berpasangan dengan teman.

Dikisahkan dalam penelitian ini awal mula subjek menghafal al-Qur'an karena tuntutan dari sekolah. Sejak kelas satu sekolah dasar (SD) mereka di ajarkan untuk menghafal surah-surah pendek hingga kelas 6 sekolah dasar (SD) 
mereka mampu menghafal juz 30. Sejak saat itu mereka termotivasi untuk terus melanjutkan hafalannya tanpa paksaan dari sekolah ataupun orang tua,

Banyak tantangan ataupun rintangan dalam menghafal al-Qur'an salah satunya adalah waktu. Menghafal al-Qur'an membutuhkan waktu yang tidak sedikit apalagi mereka juga di sibukkan dengan sekolah sehingga mereka harus memiliki strategi dalam membagi waktu. Mereka juga terkadang merasa bosan dalam menghafal al-Qur'an khususnya ketika menemukan ayat yang sulit untuk di hafalkan, godaan untuk bermain dan lain sebagainya. akan tetapi dengan keinginan yang kuat mereka mampu melalui hal tersebut.

Menghafal Al-Qur'an juga membutuhkan strategi yang tepat sehingga dapat menyeimbangkan antara menambah hafakan al-Qur'an dan belajar. Tentu setiap penghafal al-Qur'an memiliki cara ataupun metode dalam membagi waktu untuk mempertahankan hafalan mereka terlebih bagi mereka yang memiliki aktivitas lain seperti sekolah dan organisasi. Tentunya dalam dunia pendidikan peserta didik juga mengharapkan mampu bersaing dengan teman-temannya dan memiliki prestasi yang baik. Oleh sebab itu untuk mencapai keduanya (hafaalan dan prestasi), maka membutuhkan strategi yang baik pula dalam manajeman waktu.

Dalam bimbingan konseling belajar hal tersebut baik untuk diteliti, bagaimana cara siswa mempertahankan hafalan disaat ia juga harus focus dalam pendidikan. Bagaimana ia mengatur waktu agar kedua hal tersebut tetap bisa berjalan bersama. Bagaimana siswa tersebut mempertahankan hafalan di lingkungannya saat ini dan bagaimana ia berinteraksi dengan teman-teman mereka.

Terdapat beberapa jurnal yang membahas tentang menghafal al-Quran yang berkaitan dengan prestasi belajar, salah satunya studi yang dilakukan oleh Mustofa Kamal dengan judul penelitian Pengaruh pelaksanaan program menghafal Al-Qur'an terhadap prestasi belajar siswa. Hasil dari penelitian tersebut adalah bahwa Program menghafal Al-Qur'an yang dilakukan sebagian siswa MA Sunan 
Giri dapat mempengaruhi keberhasilan dan prestasi belajar siswa, bahkan menghafal bisa dapat dikatakan menjadi faktor yang penting dalam prestasi belajar siswa. Sebab dari menghafal otak anak secara tidak langsung belajar mengasah kemampuan untuk menghafal dari yang dilihat dan dibaca (Kamal, 2017). Dengan demikian si anak akan terbiasa menghafal sesuatu yang di baca dan di dengar. Ini juga mempengaruhi kecepatan otak anak dalam memproses pelajaran lain yang diterimanya.

Penelitian yang dilakukan oleh M. Hidayat Ginanjar, dosen tetap Prodi Pendidikan Agama Islam STAI Al Hidayah Bogor, berjudul Aktivitas Menghafal AlQur'an Dan Pengaruhnya Terhadap Prestasi Akademik Mahasiswa (Studi Kasus Pada Mahasiswa Program Beasiswa Di Ma'had Huda Islami, Tamansari Bogor) menunjukkan bahwa terdapat pengaruh yang sangat kuat antara aktivitas mebghafal a-Qur'an dengan prestasi akademik. Dimana Aktivitas menghafal alQur"an yang dilakukan adalah dengan cara menghafal di waktu subuh kemudian diperdengarkan kepada ustadz pembimbing, untuk disimak dan dikoreksi jika terjadi kesalahan, dan pada waktu setelah selesai sholat ashar dan setelah shalat maghrib mereka memuroja"ah (mengulang) hafalan yang telah dihafal agar lebih kuat lagi, bahkan ada mahasiswa yang berhasil menghafal 1 juz, 2 juz, dan bahkan 3 juz. Ini menunjukan bahwa kemampuan mahasiswa dalam menghafal al-qur"an menunjukan kemampuan menghafal al-Qur"an yang baik (Ginanjar, 2017).

Dari dua jurnal di atas terdapat pengaruh antara menghafal al-Qur'an dengan prestasi belajar. Oleh sebab itu tujuan penelitian ini adalah untuk mengetahui manageman waktu seorang penghafal al-Qur'an dalam meraih prestasi akademik. Karena sebagaimana yang kita ketahui seorang penghafal al-Qur'an tidak hanya unggul dalam bidang hafalan saja tetapi juga mampu bersaing dalam bidang ilmu yang lain.

\section{B. Metode}


Adapun jenis penelitian ini adalah penelitian kualitatif dengan pendekatan deskriptif. Penelitian kualitatif adalah suatu penelitian yang bertujuan untuk mendeskripsikan dan menganalisis fenomena, peristiwa, aktivitas sosial, sikap, kepercayaan, persepsi, pemikiran orang secara individual maupun kelompok (Sugiyono, 2012: 60). Dalam hal ini peneliti sebagai observer untuk mengetahui pengalaman dan strategi klien dalam mempertahankan hafalan al-Qur'an dan prestasi akademik

Dari hasil wawancara peneliti terhadap guru di SMA Muhammadiyah 2 Yogyakarta terdapat beberapa siswa yang unggul dalam bidang hafalan dan juga unggul dalam bidang akademik. Oleh sebab itu subjek penelitian berjumlah dua orang yang merupakan siswa SMA Muhammadiyah 2 Yogyakarta. Metode pengumpulan data dalam penelitian ini adalah wawancara dan observasi. Sedangkan jenis data yang berbentuk kata-kata atau deskripsi yang dihasilkan melalui wawancara dan observasi, sehingga data yang dihasilkan bukan berupa angka.

Analisis data kualitatif bersifat induktif yaitu suatu analisis berdasarkan data yang diperoleh, selanjutnya dikembangkan pola hubungan tertentu atau menjadi hipotesis (Sugiyono, 2016: 334). Di dalam pelaksanaan penelitian, peneliti akan menganalisis data dengan cara analisis deskriptif komparatif yaitu membandingkan data teori dengan data yang ada di lapangan.

\section{Pembahasan}

\section{Manajemen Waktu}

Pengertian Manajemen Dalam bahasa Inggris, management berasal dari kata to manage yang berarti mengurus, mengatur, melaksanakan dan mengelola (Echols, 2003: 372). Menurut Mary Parker Follet, sebagaimana dikutip oleh Erni, manajemen diartikan sebagai seni dalam menyelesaikan sesuatu melalui orang lain. Erni juga mengutip pendapat dari Nickels, McHugh and McHugh dalam Ernie 
Tisnawati Sule dan Kurniawan Saefullah (2008: 5-7) bahwa manajemen adalah sebuah proses yang dilakukan untuk mewujudkan tujuan organisasi melalui rangkaian kegiatan berupa perencanaan, pengorganisasian, pengarahan, dan pengendalian orang-orang serta sumber daya organisasi lainnya.

Adapun sarana atau alat manajemen untuk dapat mencapai tujuan adalah men, money, materials, machines, methods, dan markets (Manullang, 2015: 5). Manajemen juga merupakan sebuah pengambilan keputusan. Manajer harus menentukan tujuan yang akan dicapai, menentukan pihak, waktu, dan cara melaksanakan pekerjaan untuk mencapai tujuan yang telah ditentukan (Suprihanto, 2014, p. 4)

Sedangkan pengertian waktu Dalam Kamus Besar Bahasa Indonesia, waktu adalah seluruh rangkaian saat ketika proses, perbuatan, atau keadaan berada atau berlangsung (Departemen Pendidikan Nasional, 2008, p. 1554). Soeharso, sebagaimana dikutip oleh Sofyani (2012), mengemukakan bahwa waktu manusia sehari-hari dapat dikelompokkan menjadi tiga yaitu: waktu bekerja, waktu memelihara diri dan waktu luang. Maka Manajemen Waktu waktu adalah suatu ilmu dan seni yang mengatur pemanfaatan waktu secara efektif dan efisien untuk mencapai tujuan-tujuan tertentu melalui unsurunsur yang ada didalamnya. Lakein mengatakan bahwa manajemen waktu merupakan perencanaan, pengorganisasian, penggerakan, dan pengawasan produktivitas waktu. Waktu merupakan salah satu sumber daya yang harus dikelola secara efektif dan efisien untuk menunjang aktivitas (Duraisy: 2017). Dari pengertian tersebut, dapat disimpulkan bahwa manajemen waktu adalah perencanaan, pengorganisasian, penggerakan, dan pengawasan terhadap waktu agar penggunaan waktu menjadi efisien dan efektif.

Menurut Atkinson, aspek-aspek dalam manejemen waktu mencakup hal-hal berikut: 
a. Menetapkan Tujuan Menetapkan tujuan dapat membantu individu untuk memfokuskan perhatian terhadap pekerjaan yang akan dijalankan, fokus terhadap tujuan dan sasaran yang hendak dicapai serta mampu merencanakan suatu pekerjaan dalam batasan waktu yang disediakan.

b. Menyusun Prioritas Menyusun prioritas perlu dilakukan mengingat waktu yang tersedia terbatas dan tidak semua pekerjaan memiliki nilai kepentingan yang sama. Urutan prioritas dibuat berdasarkan peringkat, yaitu dari prioritas terendah hingga pada prioritas tertinggi. Urutan prioritas ini dibuat dengan mempertimbangkan hal mana yang dirasa penting, mendesak, maupun vital yang harus dikerjakan terlebih dahulu. Dalam al-maqaashid asy-syar'iyyah (inti tujuan-tujuan syariah Islam) para ulama membaginya ke dalam tiga bagian, yaitu: (1) Kebutuhan Inti atau Primer (adh-Dharuuriyyaat), adalah kebutuhan yang harus terpenuhi demi terwujudnya kebaikan dan kemaslahatan dunia dan akhirat. Jika kebutuhan tersebut tidak terpenuhi, kebaikan dunia tidak terjamin keberlangsungannya. Contohnya: pokok-pokok tujuan syariat Islam (alkulliyyaat al-khams), yaitu melindungi keselamatan agama, jiwa, akal, keturunan, dan harta. (2) Kebutuhan sekunder (al-Haajiyyaat), adalah halhal yang dibutuhkan manusia untuk mendatangkan kelapangan sekaligus untuk menghilangkan kesempitan hidup. Contohnya: adanya rukhsah dalam ibadah ketika muncul kondisi-kondisi yang menyulitkan seseorang untuk melakukan ibadah. (3) Kebutuhan tersier (at-Taahsiinaat), adalah hal-hal yang dibutuhkan sebagai kelayakan, seperti akhlak karimah dan kebiasaankebiasaan yang baik. Contohnya adalah syarat suci badan, pakaian, tempat dalam beribadah (Jawwad, 2004, p. 154). Kebutuhan primer harus paling didahulukan di antara kebutuhan sekunder dan tersier. Jika tidak, maka akan terjadi gangguan terhadap kebutuhan yang lebih tinggi prioritasnya (Jawwad, 2004, pp. 155-156). 
c. Menyusun Jadwal Aspek lainnya dalam manajemen waktu adalah membuat susunan jadwal. Jadwal merupakan daftar kegiatan yang akan dilaksanakan beserta urutan waktu dalam periode tertentu. Fungsi pembuatan jadwal adalah menghindari bentrokan kegiatan, menghindari kelupaan, dan mengurangi ketergesaan.

d. Bersikap Asertif Sikap asertif dapat diartikan sebagai sikap tegas untuk berkata "Tidak" atau menolak suatu permintaan atau tugas dari orang lain dengan cara positif tanpa harus merasa bersalah dan menjadi agresif.

e. Bersikap Tegas, merupakan strategi yang diterapkan guna menghindari pelanggaran hak dan memastikan bahwa orang lain tidak mengurangi efektivitas penggunaan waktu.

f. Menghindari Penundaan Penundaan merupakan penangguhan suatu hal hingga terlambat dikerjakan. Penundaan dalam pelaksanaan tugas dapat menyebabkan ketidakberhasilan dalam menyelesaikan pekerjaan tepat waktu, kemudian merusak jadwal kegiatan yang telah disusun secara apik serta mengganggu tercapainya tujuan yang telah ditetapkan.

g. Meminimalkan Waktu yang Terbuang Pemborosan waktu mencakup segala kegiatan yang menyita waktu dan kurang memberikan manfaat yang maksimal. Hal tersebut sering menjadi penghalang bagi individu untuk mencapai keberhasilannya karena sering membuat individu menunda melakukan kegiatan yang penting (Atkinson, 1990, p. 35).

h. Kontrol terhadap Waktu Berhubungan dengan perasaan dapat mengatur waktu dan pengkontrolan terhadap hal-hal yang dapat mempengaruhi penggunaan waktu (Macan, 1994). 
2. Managemen Waktu Penghafal Al-Qur'an Dalam Meraih Prestasi Akademik

a. Manajemen Waktu

Hasil penelitian ini mengetahui bagaimana manajemen waktu seorang penghafal al-Quran dalam meraih prestasi akademik. Managemen waktu diartikan sebagai perencanaan, pengorganisasian, pengawasan produktifitas waktu. Manajemen waktu adalah pencapaian sasaran utama kehidupan sebagai hasil dari menyisihkan kegiatan-kegiatan tidak berarti yang sering kali justru banyak memakan waktu (Ika Sandra, 2013).

Manajemen waktu yang baik sangat penting untuk mengatasi tekanantekanan dari dunia modern tanpa mengalami terlalu banyak stres. Memanage waktu dengan baik bukan berarti seorang penghafal harus melakukan banyak pekerjaan dalam waktu yang singkat, melainkan berfokus pada tugas setepatnya dan membuat perbedaan, baik di dalam pekerjaan atau di kehidupan secara keseluruhan, seorang harus belajar bagaimana mengelola waktu secara baik, yang akan membantu merasa lebih relaks, fokus, dan terkontrol.

Dalam bimbingan dan konseling belajar terdapat beberapa hal yang dapat dilakukan dalam memanajemen waktu. yaitu, 1) penetapan tujuan dan prioritas, hal ini ditetapkan sesuai dengan tanggung jawab yang dipikul oleh seseorang. 2) Mekanisme menejemen waktu, tata cara atau langkah yang harus dilakukan dalam memenejem waktu dimulai dari perencanaan sampai dengan evaluasi. 3) kontrol terhadap waktu, dilakukan dengan melakukan pengawasan terhadap alokasi waktu perkegiatan yang telah direncanakan diawal (Gea, 2014). 
b. Menetapkan tujuan dan prioritas

Tujuan ditetapkan terlebih dahulu sebelum membuat prioritas. Salah satu cara untuk memperjelas suatu prioritas adalah dengan membagi waktu yaitu strategi menggunakan waktu untuk mencapai tujuan, seperti pembuatan jadwal, daftar hal-hal yang harus dilakukan, membagi tugas (Harvard Business School Press, 2006: 5).

Subjek dalam penelitian ini memiliki tujuan mempertahankan dan meningkatkan hafalan tanpa mengesampingkan sekolah, salah satu cara dalam melakukan hal itu adalah dengan tetap mengulang hafalannya di sela-sela kegiatan sekolah. Banyaknya tugas sekolah bukan suatu hambatan untuk menambah hafalan tetapi hal ini merupakan kesempatan untuk terus menjadi lebih dewasa dengan cara mampu memanajemen waktu dengan baik.

Banyak orang yang disibukkan dengan ilmu duniawi semata sehingga melupakan bekal menuju akhirat, sementara kedua subjek dalam penelitian ini memiliki tujuan tidak hanya unggul dalam bidang ilmu akademik tetapi juga mempu melaksanakan kewajiban seorang muslim yaitu menghafal dan memahami al-Quran. Dengan menghafal al-Qur'an ia berharap dapat memberikan mahkota untuk kedua orang tuanya sebagaimana dalam hadis riwayat Hakim 1/756 dan dihasankan al-abani yang artinya:

Siapa yang menghafal al-Qur'an, mengkajinya dan mengamalkannya, maka Allah akan memberika mahkota bagi kedua orang tuanya dan cahaya yang terang seperti matahari. Dan kedua orang tuanya akan diberi dua pakaian yang tidak bisa dinilai dengan dunia. Kemudian orang tuanya bertanya, "mengapa saya sampai diberi pakaian seperti ini?" lalu disampaikan kepadanya "sebab anakmu telah mengamalkan al-Qur'an." (HR. Hakim 1/756 dan di hasankan al-Abani) 
c. Perencanaan dan penjadwalan

Perencanaan dikenal dengan membuat daftar harian, untuk mengelola manajemen waktu yang baik yaitu dengan cara membuat daftar perencanaan terkait hal-hal yang akan dilakukan, sehingga akan membantu seseorang untuk memilah tugas atau pekerjaan yang penting terlebih dahulu yang harus dilakukan daripada melakukan sesuatu hal yang bukan merupakan priotas utama terlebih dahulu. Untuk itu perlu mengelompokkan setiap kegiatan yang akan dilakukan dalam buku harian supaya dapat mengetahui mana tugas yang harus diselesaikan sekarang dan tugas yang boleh ditunda (Yuswardi et al., 2016).

Kedua subjek telah memiliki perencanaan yang matang dan selalu di lakukan setiap hari. Mereka meletakkan waktu untuk menambah hafalan setelah sholat magrib hingga menjelang Isya dan dilanjutkan setelah sholat isya hingga jam 8 malam. Waktu mempertahankan hafalan biasanya sebelum dan setelah sholat subuh. Dengan demikian mereka juga memiliki banyak waktu untuk belajar dan menyelesaikan tugas sekolah. Ketika waktu luang (libur) mereka akan menyempatkan diri muraja'ah (mengulang-ngulang hafalan).

Waktu digunakan untuk belajar dan menghafal akan tetapi tidak menjadikan mereka anti sosial. Sebagaimana data yang didapatkan mereka mampu bersosialisasi dengan teman-teman mereka khususnya di sekolah. Namun mereka juga memilih bergaul dengan orang-orang yang membawa dampak baik baginya, karena mereka takut terpengaruh dengan lingkungan yang buruk apalagi mereka mamasuki usia remaja, usia yang mudah labil.

Jadwal yang mereka tetapkan untuk menghafal atau menambah hafalan dan belajar selalu mereka rutinkan. Apabila ada hal yang menghambatnya maka yang mereka lakukan adalah menggantinya dengan waktu yang lain. Dengan adanya jadwal yang telah dibuat menjadikan 
mereka disiplin bukan hanya dalam menghafal tapi disiplin dalam kegiatan yang lain.

d. Kemampuan mengendalikan waktu

Kemampuan dalam mengendalikan waktu dan menggunakan waktu yang ada secara produktif berbeda-beda pada setiap orang. Kemampuan mengendalikan waktu adalah tata cara atau langkah-langkah yang harus dilakukan dari mulai perencanaan sampai dengan evaluasi (Nurhidayati, 2016), untuk mencapai beberapa tujuan dalam kehidupan serta menghasilkan kesejahteraan.

Dalam hal ini subjek mampu menggunakan waktu dengan baik sesuai dengan tujuannya, yaitu dengan membuat jadwal harian dan menerapkannya dalam kehidupan sehari-hari. Ia juga mempu menentukan kegiatan-kegiatan yang dapat menambah wawasan dan meninggalkan halhal yang dapat menghambat dalam mencapai tujuannya. Prinsipnya adalah dalam menghafal bukan mencari waktu luang tetapi meluangkan waktu untuk al-Quran. Sehingga tidak ada kata sibuk atau alasan berupa banyak tugas yang harus dikerjakan sehingga tidak membaca al-Quran, tetapi subjek mencari waktu untuk membaca al-Quran.

Diri kita sendiri yang mengendalikan waktu, jika pengendalian waktu baik maka kita akan mudah mencapai tujuan, sebaliknya juga pengendalian waktu yang kurang maka kita akan dihanyutkan oleh waktu tersebut tanpa menghasilkan apa-apa atau dengan kata lain waktu kita akan terbuang siasia.

Usia remaja merupakan usia yang masih labil, memasuki usia yang mulai tertarik pada lawan jenis dan ingin terlihat menarik didepannya. Begitu pula yang dialami oleh kedua subjek ini, tetapi mereka mampu membentengi diri dari hal-hal yang dapat menghambat proses pencapaian tujuan mereka. Baginya "masih ada yang lebih bermanfaat dari pada 
menuruti hawa nafsu, jodoh juga akan datang jika sudah waktunya, saat ini yang lebih penting adalah mempersiapkan diri dengan baik untuk menjemput jodoh yang baik pula" (Responden P, 2019).

e. Evaluasi

Evaluasi yang dimaksud adalah mengetahui kebiasaan penggunaan waktunya, seseorang bisa menggunakan catatan penggunaan waktunya selama satu minggu dan diperiksa kembali pada akhir pekan. Pencatatan dan pemeriksaan ini penting untuk mengevaluasi banyak waktu yang dihabiskan untuk aktivitas yang berorientasi pada tujuan dan menjadi prioritas, serta berapa banyak waktu yang dihabiskan untuk aktivitas rutin maupun aktivitas tanpa tujuan dan prioritas. Dalam hal ini Subjek tidak memiliki catatan mengenai kegiatan sehari-hari tetapi biasanya sebelum tidur ia intropeksi diri untuk menjadi lebih baik dan merencanakan apa yang akan ia kerjakan di esok hari.Selain itu dalam satu minggu atau satu bulan mereka akan muroja'ah untuk mengetahui atau mengevaluasi hafalan mereka.

Dalam bidang akademik mereka mampu bersaing dengan temanteman sekolahnya, dan memiliki nilai yang memuaskan. Begitupula dalam bidang non akademik mereka juga memiliki prestasi sebagai berikut: juara hafalan qur'an, Tahsin, Qiro'ah, Tartil, Badmintoon dan lain sebagainya.

Menghafal al-Qur'an memiliki dampak positif dalam menuntut ilmu salah satunya adalah di mudahkan memahami ilmu yang di sampaikan, mudah menangkap aapa yang disampaikan oleh guru, dan mudah dalam hal menghafal mata pelajaran yang diberikan. Dengan demikian menghafal alqur'an tidak akan menghambat seseorang untuk memperoleh ilmu pengetahuan, ilmu yang didapatkan juga tidak mudah dilupakan.

Selain itu berdampak pula pada lingkungan sekolah, ada beberapa teman yang terinspirasi dengan subjek untuk menghafal al-Qur'a, belajar 
tahsin, belajar membaca al-Qur'an. Mereka juga terkadang belajar bersama khususnya dalam bidang membaca dan menghafal al-Qur'an Sehingga mereka merasa ilmu yang telah di dapatkannya tidak sia-sia dan berguna untuk lingkungan sekitar.

\section{Simpulan}

Berdasarkan uraian hasil penelitian di atas maka dapat di tarik kesimpulan bahwa manajemen waktu penghafal al-Quran dalam meraih prestasi akademik dan mempertahankan hafalan menggunakan 4 cara yaitu :

1. Menentukan tujuan dan prioritas dimana tujuan kedua subjek ini adalah menambah dan mempertahankan hafalan tanpa mengesampingkan sekolah atau dengan kata lain berusaha untuk meraih prestasi akademik

2. Perencanaan dan penjadwalan, kedua subjek memiliki perencanaan yang matang dan dilakukan setiap hari. Keduanya memiliki waktu khusus dalam menambah hafalan, muroja'ah hafalan dan mengerjakan tugas sekolah

3. Kemampuan mengendalikan waktu, dalam artian bahwa subjek mampu menggunakan waktu dengan baik sesuai dengan tujuannya, dengan bantuan jadwal harian yangt telah dibuat dan menerapkannya dalam kehidupan sehari-hari, serta menentukan kegiatan yang bermanfaat dan yang tidak bermanfaat

4. Evaluasi. Evaluasi yang biasanya dilakukan adalah intropeksi diri sebelum tidur, dan merencanakan apa yang akan dilakukan esok hari. Selain itu mereka juga akan mengevaluasi hafalan dan hasil belajar mereka setiap bulan.

\section{DAFTAR PUSTAKA}

Atkinson. (1990). Manajemen Waktu yang Efektif. Jakarta: Binarupa Aksara. Departemen Pendidikan Nasional. (2008). Kamus besar bahasa Indonesia Pusat Bahasa (4th ed.). jakarta: Gramedia Pustaka Utama.

Echols, J. M. (2003). Kamus Indonesia-Inggris. Jakarta: Gramedia Pustaka Utama. 
Gea, A. A. (2014). Time Management: Menggunakan Waktu Secara Efektif dan Efisien. Humaniora, 5(2), 777. https://doi.org/10.21512/humaniora.v5i2.3133

Ginanjar, M. H. (2017). Aktivitas Menghafal Al-Qur'an Dan Pengaruhnya Terhadap Prestasi Akademik Mahasiswa (Studi Kasus Pada Mahasiswa Program Beasiswa Di Ma'had Huda Islami, Tamansari Bogor). Edukasi Islami: Jurnal Pendidikan Islam, 6(11), 20. https://doi.org/10.30868/ei.v6i11.94

Harvard Business School Press. (2006). Managing Time: Expert Solutions to Everyday Challenges. Harvard: Harvard Business Press.

Ika Sandra, K. (2013). Manajemen Waktu, Efikasi-Diri Dan Prokrastinasi. Persona:Jurnal Psikologi Indonesia, https://doi.org/10.30996/persona.v2i3.140

Jawwad, M. A. (2004). Menjadi Manajer Sukses (A. H. al Kattani, Trans.). Jakarta: Gema Insani.

Kamal, M. (2017). Pengaruh Pelaksanaan Program Menghafal Al-Qur'an Terhadap. Prestasi Belajar Siswa. Tadarus: Jurnal Pendidikan Islam, 6, No. 2.

Macan, T. H. (1994). Time management: Test of a process model. Journal of Applied Psychology, 79(3), 381-391. https://doi.org/10.1037/0021-9010.79.3.381

Manullang, M. (2015). Dasar-Dasar Manajemen. Yogyakarta: Gadjah Mada University Press.

Nurhidayati, D. D. (2016). Peningkatan Pemahaman Manajemen Waktu Melalui Bimbingan Kelompok Dengan Teknik Problem Solving pada Siswa. PSIKOPEDAGOGIA Jurnal Bimbingan Dan Konseling, 5(1), 24. https://doi.org/10.12928/psikopedagogia.v5i1.4592

Octavia, S. A. (2019). Implementasi Manajemen Bimbingan Konseling Di Sekolah/ Madrasah. Yogyakarta: Deepublish.

Rusyadi, S. H. (2012). Hubungan antara Manajemen Waktu dengan Prestasi Belajar pada Mahasiswa [Skripsi]. Universitas Muhammadiyah Surakarta.

Sugiyono. (2012). Memahami Penelitian Kualitatif. Alfabeta.

Sugiyono. (2016). Metode Penelitian Pendidikan Pendekatan Kuantitatif, Kualitatif dan $R \& D$. Alfabeta.

Sule, E. T., \& Saefullah, K. (2008). Pengantar Manajemen. Kencana Prenada Media Group.

Suprihanto, J. (2014). Manajemen. Gadjah Mada University Press.

Yuswardi, Y., Rizal, R., \& Fajri, M. (2016). Manajemen Waktu Mahasiswa Kurikulum Berbasis Kompetensi Fakultas Keperawatan Universitas Syiah Kuala. Idea Nursing Journal, 7(3), 66-72. 